\title{
Electropolymerized Polypyrrole Nanocomposites with Cobalt Oxide Coated on Carbon Paper for Electrochemical Energy Storage
}

\author{
Huige Wei ${ }^{\mathrm{a}, \mathrm{b}}$, Cuizhu $\mathrm{He}^{\mathrm{c}}$, Jiurong Liu ${ }^{\mathrm{c}, *}$, Hongbo Gu, ${ }^{\mathrm{d}}$ Yiran Wang ${ }^{\mathrm{a}}$, Xingru Yan ${ }^{\mathrm{a}}$, \\ Jiang Guo ${ }^{a}$, Daowei Ding ${ }^{b}$, Nancy Z Shen ${ }^{\mathrm{b}}$, Xuefeng Wang ${ }^{\mathrm{d}}$, Suying Wei ${ }^{\mathrm{b}}$ e," \\ and Zhanhu Guo a,* \\ ${ }^{a}$ Integrated Composites Laboratory (ICL), Department of Chemical and Biomolecular \\ Engineering, The University of Tennessee, Knoxville, TN 37996 USA \\ ${ }^{\mathrm{b}}$ Dan F. Smith Department of Chemical Engineering \\ Lamar University, Beaumont, TX 77710 USA
}

${ }^{c}$ Key Laboratory for Liquid-Solid Structural Evolution and Processing of Materials, Ministry of Education and School of Materials Science and Engineering, Shandong University, Jinan, Shandong 250061 China

${ }^{\mathrm{d}}$ Department of Chemistry, Key Laboratory of Yangtze River Water Environment, Ministry of Education, Tongji University, Shanghai 200092 China

${ }^{\mathrm{e}}$ Department of Chemistry and Biochemistry, Lamar University, Beaumont, TX 77710 USA

*Authors to whom correspondence should be addressed.

E-mail: zguo10@utk.edu (Z.G.); jrliu@sdu.edu.cn (J. L.); swei@lamar.edu (S.W.) 


\begin{abstract}
Polypyrrole (PPy)/cobalt oxide $\left(\mathrm{Co}_{3} \mathrm{O}_{4}\right) /$ carbon paper $(\mathrm{CP})$ ternary composites prepared by potentiodynamic electropolymerization of pyrrole monomers onto flower-like $\mathrm{Co}_{3} \mathrm{O}_{4}\left(\mathrm{f}-\mathrm{Co}_{3} \mathrm{O}_{4}\right)$ nanoparticles coated on $\mathrm{CP}\left(\mathrm{PPy} / \mathrm{f}-\mathrm{Co}_{3} \mathrm{O}_{4} / \mathrm{CP}\right)$ were studied serving as electrode materials for supercapacitor applications. The $\mathrm{f}-\mathrm{Co}_{3} \mathrm{O}_{4}$ with unique porous morphology on $\mathrm{CP}$ was first obtained by drop casting $\mathrm{Co}_{3} \mathrm{O}_{4}$ ethanol suspensions onto $\mathrm{CP}$. Ball-like $\mathrm{Co}_{3} \mathrm{O}_{4}\left(\mathrm{~b}-\mathrm{Co}_{3} \mathrm{O}_{4}\right)$ with dense structure was also prepared for comparison. The electrochemical results including cyclic voltammetry $(\mathrm{CV})$ and galvanostatic charge-discharge (GCD) in $2.0 \mathrm{M} \mathrm{KOH}$ aqueous solution revealed that the $\mathrm{PPy} / \mathrm{Co}_{3} \mathrm{O}_{4} / \mathrm{CP}$ ternary composites exhibited superior supercapacitive performances than both $\mathrm{f}-\mathrm{Co}_{3} \mathrm{O}_{4} / \mathrm{CP}$ and $\mathrm{b}-\mathrm{Co}_{3} \mathrm{O}_{4} / \mathrm{CP}$. Specifically, a specific capacitance of 398.4 F/g was obtained for the PPy/f- $\mathrm{Co}_{3} \mathrm{O}_{4} / \mathrm{CP}$, much higher than that of 40.9 and $22.0 \mathrm{~F} / \mathrm{g}$ for $\mathrm{f}-\mathrm{Co}_{3} \mathrm{O}_{4} / \mathrm{CP}$ and b- $\mathrm{Co}_{3} \mathrm{O}_{4} / \mathrm{CP}$, respectively. The electrochemical impedance spectroscopy studies suggested that better capacitive properties in $\mathrm{PPy} / \mathrm{f}-\mathrm{Co}_{3} \mathrm{O}_{4} / \mathrm{CP}$ were attributed to the pseudocapacitive contributions from the PPy nanocoating and greatly reduced charge transfer resistance in the composites. $\mathrm{PPy} / \mathrm{f}-\mathrm{Co}_{3} \mathrm{O}_{4} / \mathrm{CP}$ also displayed an excellent cycling stability with negligible capacitance loss after 1000 cycles.
\end{abstract}

Keywords: Cobalt oxide; Polypyrrole; Carbon paper; Composites; Supercapacitor 


\section{Introduction}

Conductive polymers and their composites have emerged as new materials of great potential considering their cost-effective processability, lightweight, tunable mechanical and magnetic properties, and environmental friendliness [1,2]. Versatile applications for electrocatalysts [3], sensors [4,5], anticorrosion [6], carbon dioxide captures [7], nanofiltration membranes for separating organic mixtures [8], light emitting diodes [9], electrochromic devices [10], batteries [11], and electrochemical capacitors [12,13] have been explored till now. Among the conductive polymers including polyaniline (PANI) [14-16], polythiophenes and their derivatives [17], poly (DNTD) [18,19], polypyrrole (PPy) has received more attention for the easy oxidation, water solubility, and commercial availability of pyrrole monomers [20]. Recently, PPy composites used for supercapacitors have been intensively studied due to their fast electrochemical switching, good redox reversibility, and high pseudocapacitance values [21]. For example, carbon materials such as graphene [22], carbon nanotubes [23] and carbon nanofibers [24] were introduced to PPy matrix for improving the electrical conductivity and rate capability of the electrode. Our previous work has also demonstrated the feasibility of preparing uniform PPy nanocoatings on carbon paper $(\mathrm{CP})$ using potentiodynamic electropolymerization technique at lower scan rates. However, the improvement of the supercapacitive performance is limited due to low capacitances and energy densities of the carbons [25]. Therefore, PPy incorporated with materials of higher capacitances has been investigated, for example, transition metal oxides including $\mathrm{RuO}_{2}$ [26], $\mathrm{MnO}_{2}$ [27], $\mathrm{CoO}$ [28], $\mathrm{V}_{2} \mathrm{O}_{5}$ [29], and $\mathrm{MoO}_{3}$ [30], as well as conductive polymers such as PANI [31]. Of all the transition metal oxides, $\mathrm{Co}_{3} \mathrm{O}_{4}$ is considered as a promising candidate in view of its relatively low cost, high theoretical capacitance of $3560 \mathrm{~F} / \mathrm{g}$ [32], and excellent redox activities. Via the reversible faradic redox reactions, $\mathrm{Co}_{3} \mathrm{O}_{4}$ exhibits excellent electrochemical 
behavior with its ability to interact with electrolyte ions not only at the surface, but also throughout the bulk in alkaline solutions [33]. The other advantage of $\mathrm{Co}_{3} \mathrm{O}_{4}$ is its controllable size and shape, tunable surface, and structural properties. Nanoparticles [34], nanorods [35], and nanowires [36] have been synthesized through the hydro-thermal/solvothermal route. A proper morphology and optimized microstructure will endow $\mathrm{Co}_{3} \mathrm{O}_{4}$ based electrodes with high specific surface areas and facilitated electrolyte ion transport [37]. For example, Dong et al. reported chemical oxidative polymerization of pyrrole monomers in the presence of $\mathrm{Co}_{3} \mathrm{O}_{4}$ particles to form PPy and $\mathrm{Co}_{3} \mathrm{O}_{4}$ power composites, and then prepared stable films for the immobilization of hemoglobin and glucose oxidase by dissolving the composites in ionic liquids [38]. Liu et al. also studied the reduced graphene oxide- $\mathrm{PPy}^{-} \mathrm{Co}_{3} \mathrm{O}_{4}$ ternary composites for microwave absorption [39]. Yet, to couple $\mathrm{Co}_{3} \mathrm{O}_{4}$ with PPy for energy storage applications, to the best of our knowledge, has rarely been reported.

Herein, PPy ternary composites via electropolymerization of pyrrole monomers onto carbon paper $(\mathrm{CP})$ modified with $\mathrm{Co}_{3} \mathrm{O}_{4}$ were prepared for supercapacitor applications. Two different structured cobalt oxides, i.e., flower-like cobalt oxide $\left(\mathrm{f}-\mathrm{Co}_{3} \mathrm{O}_{4}\right)$ and ball-like cobalt oxide (b$\left.\mathrm{Co}_{3} \mathrm{O}_{4}\right)$ were first synthesized through a facile solvothermal method. The structure and morphology of the cobalt oxides were examined by X-ray powder diffraction (XRD) and field emission scanning electron microscope (FE-SEM). The f- $\mathrm{Co}_{3} \mathrm{O}_{4} / \mathrm{CP}$ and $\mathrm{b}-\mathrm{Co}_{3} \mathrm{O}_{4} / \mathrm{CP}$ electrodes were prepared by drop casting the two structured cobalt oxide ethanol suspensions onto $\mathrm{CP}$, respectively. PPy/f- $-\mathrm{Co}_{3} \mathrm{O}_{4} / \mathrm{CP}$ ternary composites were fabricated by electropolymerization of pyrrole monomers on the pre-obtained $\mathrm{f}_{-}-\mathrm{Co}_{3} \mathrm{O}_{4} / \mathrm{CP}$. Supercapacitive performances of the f$\mathrm{Co}_{3} \mathrm{O}_{4} / \mathrm{CP}, \mathrm{b}-\mathrm{Co}_{3} \mathrm{O}_{4} / \mathrm{CP}$, and $\mathrm{PPy} / \mathrm{f}-\mathrm{Co}_{3} \mathrm{O}_{4} / \mathrm{CP}$ were evaluated using cyclic voltammetry $(\mathrm{CV})$, 
galvanostatic charge-discharge (GCD), and electrochemical impedance spectroscopy measurements.

\section{Experimental}

\subsection{Materials}

The carbon paper $\left(\mathrm{CP}\right.$, thickness: $0.010 \pm 0.001$ inch, density: $0.46 \mathrm{~g} / \mathrm{cm}^{3}$, mean pore diameter: $30 \mu \mathrm{m}$, electrical resistivity: $2 \Omega / \mathrm{cm}$ ) was provided by Fuel Cell Store. Cobalt acetate tetrahydrate $\left(\mathrm{Co}\left(\mathrm{CH}_{3} \mathrm{COO}\right)_{2} \cdot 4 \mathrm{H}_{2} \mathrm{O}\right.$, analytical grade), methanol (analytical grade) and polyvinylpyrrolidone (PVP, K30 with average Mw 40,000) were purchased from Sinopharm Chemical Reagent Co., Ltd. All the chemicals were used as received without any further treatment.

\subsection{Preparation of $f-\mathrm{Co}_{3} \mathrm{O}_{4}$ and $b-\mathrm{Co}_{3} \mathrm{O}_{4}$}

The cobalt oxides were synthesized through a facile solvothermal method. Specifically, for f$\mathrm{Co}_{3} \mathrm{O}_{4}, 2 \mathrm{mmol}$ cobalt acetate $\left(\mathrm{Co}\left(\mathrm{CH}_{3} \mathrm{COO}\right)_{2} \cdot 4 \mathrm{H}_{2} \mathrm{O}\right)$ and 1.0 g polyvinyl-pyrrolidone (PVP, K30) were dissolved in $40 \mathrm{~mL}$ methanol under magnetic stirring. The resulting red solution was transferred into a $100 \mathrm{~mL}$ Teflon-lined stainless steel autoclave, sealed, and subsequently heated in an oven at $453 \mathrm{~K}$ for $3 \mathrm{~h}$. The intermediate precursor of $\mathrm{Co}(\mathrm{OH})_{2}$ was centrifuged and washed using deionized water and ethanol for five times, respectively, and dried in vacuum. The asprepared precursor was then annealed at $623 \mathrm{~K}$ for $3 \mathrm{~h}$ to give the final $\mathrm{f}-\mathrm{Co}_{3} \mathrm{O}_{4}$ product. In the case of the synthesis of $\mathrm{b}-\mathrm{Co}_{3} \mathrm{O}_{4}, 2 \mathrm{mmol}$ cobalt acetate $\left(\mathrm{Co}\left(\mathrm{CH}_{3} \mathrm{COO}\right)_{2} \cdot 4 \mathrm{H}_{2} \mathrm{O}\right), 4 \mathrm{mmol}$ urea and 0.5 g polyvinyl-pyrrolidone (PVP, K30) were dissolved in $40 \mathrm{~mL}$ methanol under magnetic stirring. The solution was transferred into a $100 \mathrm{~mL}$ Teflon-lined stainless steel autoclave, sealed, 
and then heated in an oven at $473 \mathrm{~K}$ for $6 \mathrm{~h}$. The precursor of $\mathrm{Co}(\mathrm{OH})_{2}$ was centrifuged and washed using deionized water and ethanol for five times, respectively, and then dried in vacuum. The as-prepared precursor was subject to annealing at $773 \mathrm{~K}$ for $2 \mathrm{~h}$ to yield the final $\mathrm{b}-\mathrm{Co}_{3} \mathrm{O}_{4}$ product.

\subsection{Fabrication of $\mathrm{Co}_{3} \mathrm{O}_{4} / \mathrm{CP}$ and $\mathrm{PPy} / \mathrm{f}-\mathrm{Co}_{3} \mathrm{O}_{4} / \mathrm{CP}$ electrodes}

To obtain the $\mathrm{Co}_{3} \mathrm{O}_{4} / \mathrm{CP}$ composite electrode, $\mathrm{f}-\mathrm{Co}_{3} \mathrm{O}_{4}$ or b- $\mathrm{Co}_{3} \mathrm{O}_{4}$ was dispersed in ethanol (1 mg cobalt oxide per $1 \mathrm{~mL}$ ethanol) by sonication, and then the dispersion was drop-casted onto the $\mathrm{CP}(1 \mathrm{~cm} \times 1 \mathrm{~cm})$ and dried in air. The mass of the $\mathrm{Co}_{3} \mathrm{O}_{4}$ on $\mathrm{CP}$ was controlled to be around 1 mg. The polypyrrole modified electrode was prepared by potentiodynamic electropolymerization of pyrrole monomers onto the $\mathrm{f}-\mathrm{Co}_{3} \mathrm{O}_{4} / \mathrm{CP}$ composite performed on an electrochemical working station VersaSTAT 4 potentiostat (Princeton Applied Research) at room temperature. A typical electrochemical polymerization was performed using $\mathrm{Co}_{3} \mathrm{O}_{4} / \mathrm{CP}$ as the working electrode, saturated calomel electrode (SCE) as the reference electrode, and a platinum $(\mathrm{Pt})$ wire as the counter electrode. The electropolymerizaton was scanned back and forth from 0 to $+1.2 \mathrm{~V}$ vs. $\mathrm{SCE}$ at a scan rate of $50 \mathrm{mV} / \mathrm{s}$ for two cycles in aqueous solution containing $0.05 \mathrm{M}$ pyrrole monomers and $0.1 \mathrm{M} \mathrm{KNO}_{3}$.

\subsection{Characterizations}

X-ray powder diffraction (XRD) pattern of the cobalt oxides was obtained by a Rigaku D/Max RC X-ray diffractometer with Ni filtered $\mathrm{Cu} \mathrm{K} \alpha$ radiation $(\mathrm{V}=40 \mathrm{kV}, \mathrm{I}=50 \mathrm{~mA})$ at a scanning rate of $4 \% \mathrm{~min}$. Correspondingly, their microstructures were examined using a JSM6700F field emission scanning electron microscope (FE-SEM) at an accelerating voltage of 20 $\mathrm{kV}$ and electric current of $1.0 \times 10^{-10} \mathrm{~A}$, and a JEOL JEM-2100 high-resolution TEM (HR-TEM) 
operated at $200 \mathrm{kV}$. Fourier transform infrared spectrometer (FT-IR) was recorded on a VERTEX-70 FT-IR spectrometer.

The specific Brunauer-Emmett-Teller (BET) surface areas and pore-size distributions of the cobalt oxides were measured on a Quantachrome Nova 2200e by nitrogen adsorption at 77.4 K. Prior to each measurement, samples were degassed at $300{ }^{\circ} \mathrm{C}$ for $8 \mathrm{~h}$ under high vacuum $(<0.01$ mbar). The mesopore-size distribution was calculated using the Barrett-Joyner-Halenda (BJH) method from the desorption isotherm. Optical properties of cobalt oxides were carried out on a UV-VIS-NIR spectrophotometer (Jasco V-670) by dispersing the powders by sonication in ethanol to obtain dilute solutions.

The electrochemical measurements of the $\mathrm{Co}_{3} \mathrm{O}_{4} / \mathrm{CP}$ and $\mathrm{PPy} / \mathrm{f}-\mathrm{Co}_{3} \mathrm{O}_{4} / \mathrm{CP}$ composites were carried out on the VersaSTAT 4 potentiostat in $2.0 \mathrm{M} \mathrm{KOH}$ aqueous solution in a three-electrode setup with the $\mathrm{Co}_{3} \mathrm{O}_{4} / \mathrm{CP}$ or PPy/f- $\mathrm{Co}_{3} \mathrm{O}_{4} / \mathrm{CP}$ electrode serving as the working electrode, SCE as the reference electrode, and Pt wire as the counter electrode. The cyclic voltammetry (CV) was scanned from -0.1 to $0.5 \mathrm{~V}$ vs. SCE at a series of scan rates ranging from 200 to $10 \mathrm{mV} / \mathrm{s}$. The galvanostatic charge-discharge (GCD) was performed at current densities from 50 to $10 \mathrm{~A} / \mathrm{g}$. Electrochemical impedance spectroscopy (EIS) was carried out in the frequency range of 100, 000 to $0.01 \mathrm{~Hz}$ at a $5 \mathrm{mV}$ amplitude referring to the open circuit potential. All the characterizations were carried out at room temperature in air.

\section{Results and discussions}

\subsection{Synthesis and characterization of $f-\mathrm{Co}_{3} \mathrm{O}_{4}$ and $b-\mathrm{Co}_{3} \mathrm{O}_{4}$}




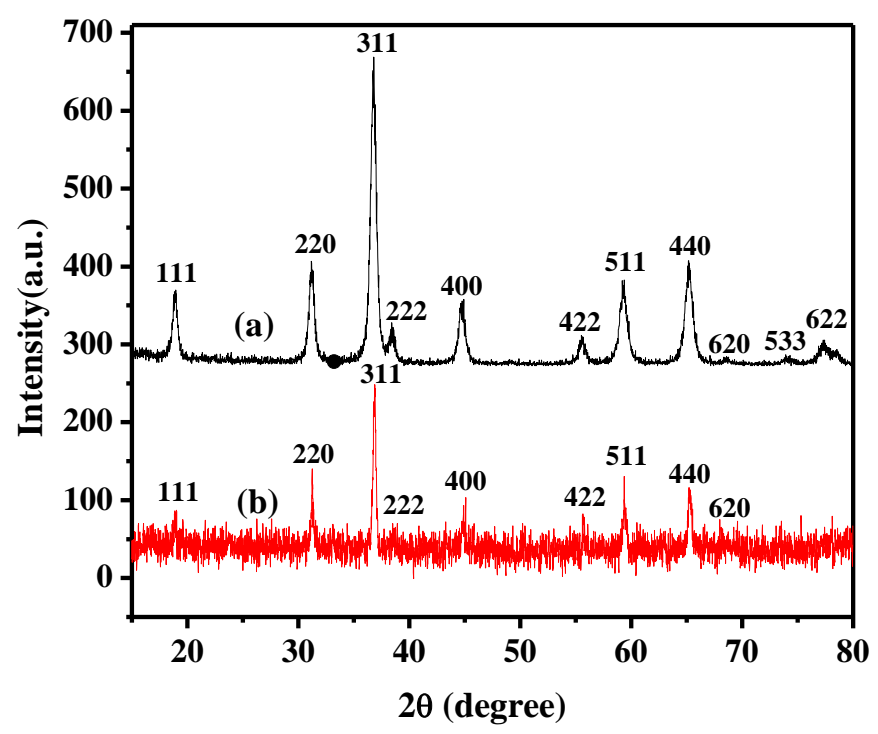

Fig. 1. XRD patterns of (a) f- and (b) b- $\mathrm{Co}_{3} \mathrm{O}_{4}$.

To examine the crystalline structure of the cobalt oxides obtained, XRD patterns of both samples was collected, Fig. 1. All diffraction peaks could be indexed to $\mathrm{Co}_{3} \mathrm{O}_{4}$ (JCPDS card No.43-1003) [40], and no peak of other phases was detected, indicative of the high purity of the cubic $\mathrm{Co}_{3} \mathrm{O}_{4}$ phase obtained in the present work. 


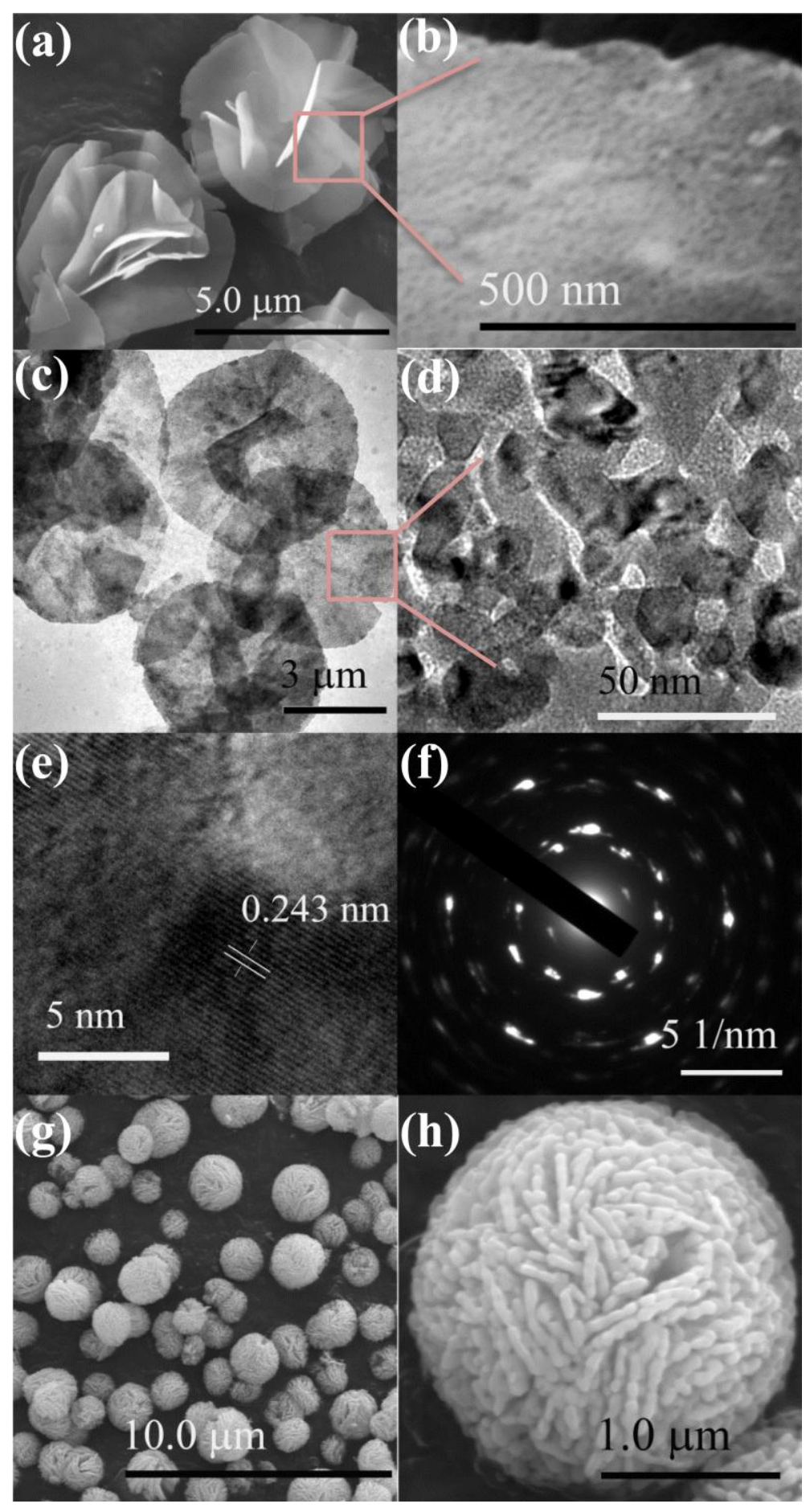

Fig. 2. SEM and HRTEM images of $\mathrm{f}-\mathrm{Co}_{3} \mathrm{O}_{4}$ at lower (a), (c), and (b), (d) higher magnifications, respectively; (e) lattice resolved HRTEM image of a single $\mathrm{f}-\mathrm{Co}_{3} \mathrm{O}_{4}$ nanocrystal and (f) the selected area electron diffraction (SAED) pattern obtained by the converge beam; SEM images of $\mathrm{b}-\mathrm{Co}_{3} \mathrm{O}_{4}$ at lower $(\mathrm{g})$ and $(\mathrm{h})$ higher magnifications. 
Morphology plays a critical role in determining the supercapacitive performances of the electrode material, where a proper morphology and optimized microstructure will enable electrodes with high specific surface areas and facilitate electrolyte ion transport [41]. Therefore, SEM and TEM were utilized to characterize the morphology and structure of the cobalt oxides, Fig. 2. The SEM image reveals flower-like structure with a diameter of approximately 4-5 $\mu \mathrm{m}$ for the monodispersed $\mathrm{f}_{-} \mathrm{Co}_{3} \mathrm{O}_{4}$, Fig. 2a. A higher magnification SEM image, Fig. 2b, shows that the flower-like structure is composed of two-dimensional petaloid nanosheets, from which a lot of pores are observed. To obtain further information on the porous structures, HR-TEM images of the $\mathrm{f}-\mathrm{Co}_{3} \mathrm{O}_{4}$ are present in Fig. 2c. The apparent contrast between the white part and the black ligaments also confirms the nanoporous wormhole-like characteristic of the pores, Fig. 2d, and the pore size is measured ca. 5-10 nm. From the HRTEM image, Fig. 2e, the typical lattice fringe spacing is measured to be $0.243 \mathrm{~nm}$, corresponding to the (311) crystal plane of cubic $\mathrm{Co}_{3} \mathrm{O}_{4}$ [42]. The corresponding selected area electron diffraction (SAED) pattern, Fig. 2f, indicates a polycrystalline structure of the porous structures. Differed from f- $\mathrm{Co}_{3} \mathrm{O}_{4}, \mathrm{~b}-\mathrm{Co}_{3} \mathrm{O}_{4}$ displays a dense microsphere structure with a diameter of approximately 1-2 $\mu \mathrm{m}$, Fig. $2 \mathrm{~g}$. The microspheres are built of nanorods about 100-300 $\mathrm{nm}$ in length at a higher magnification, Fig. $2 \mathrm{~h}$. The nanoporous structure in $\mathrm{f}-\mathrm{Co}_{3} \mathrm{O}_{4}$ is expected to be more favorable for the access of ions to the electrode material and help achieve more desirable supercapacitive performances.

BET gas-sorption measurements were carried out to investigate the specific surface area and pore size distributions of the two cobalt oxides. Desirable electrode materials are proposed to be featured with macropores ( $>50 \mathrm{~nm}$ ) serving as ion reservoirs to reduce ion diffusion distances to the interior surfaces, mesopores (between 2 and $50 \mathrm{~nm}$ ) providing low-resistive pathways for ions through the porous particles, and micropores $(<2 \mathrm{~nm})$ to enhance electric double layer 
capacitance [43]. Fig. 3 shows the nitrogen adsorption-desorption isotherms of the cobalt oxide samples and the corresponding Barrett-Joyner-Halenda $(\mathrm{BJH})$ pore size distribution obtained from the desorption branch in the insets. The $\mathrm{f}-\mathrm{Co}_{3} \mathrm{O}_{4}$ exhibits a typical IV type curve of the mesoporous structure [37], which can be further confirmed by the BJH pore size distribution plot, Fig. 3a. The uptake of $\mathrm{N}_{2}$ at higher relative pressure $\left(\mathrm{P} / \mathrm{P}_{\mathrm{o}}>0.9\right)$ in the BET isotherm suggests the existence of macropores in the sample [44]. The pore size distribution plot also verifies the presence of micro- and meso pores in the material with a pore size distribution maxima centered at $\sim 6 \mathrm{~nm}$. A BET specific surface area of around $44.31 \mathrm{~m}^{2} / \mathrm{g}$ and a total pore volume of 0.17 $\mathrm{cm}^{3} / \mathrm{g}$ are also determined for the $\mathrm{f}-\mathrm{Co}_{3} \mathrm{O}_{4}$. In the case of $\mathrm{b}-\mathrm{Co}_{3} \mathrm{O}_{4}$, a similar nitrogen adsorptiondesorption isotherm with a larger pore size distribution maxima centered at $\sim 26 \mathrm{~nm}$ is obtained, Fig. 3b. Compared to $\mathrm{f}-\mathrm{Co}_{3} \mathrm{O}_{4}, \mathrm{~b}-\mathrm{Co}_{3} \mathrm{O}_{4}$ possesses much lower specific surface area and total pore volume, $3.62 \mathrm{~m}^{2} / \mathrm{g}$ and a $0.05 \mathrm{~cm}^{3} / \mathrm{g}$, respectively. The superior physiochemical properties of $\mathrm{f}-\mathrm{Co}_{3} \mathrm{O}_{4}$ than those of $\mathrm{b}-\mathrm{Co}_{3} \mathrm{O}_{4}$ render the former more suitable for supercapacitor electrodes than the latter. 

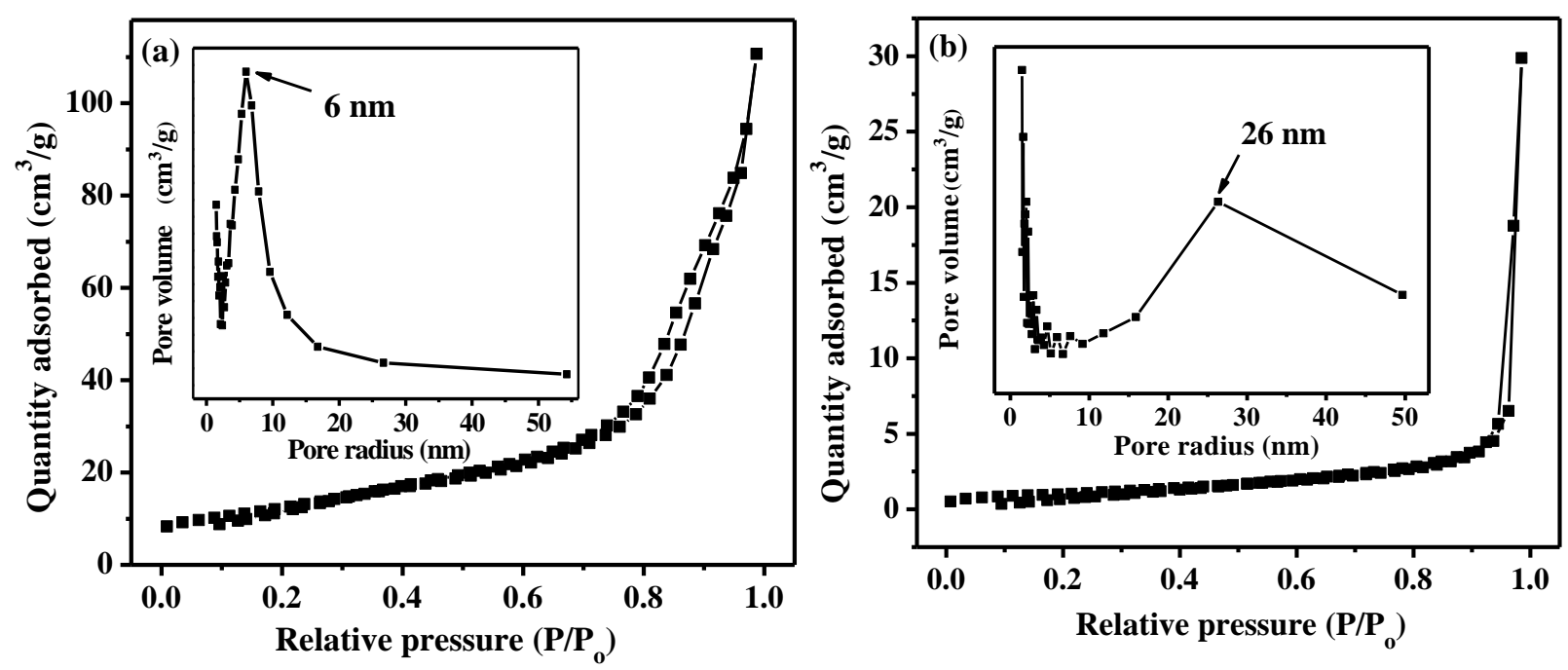

Fig. 3. BET isotherms of (a) $\mathrm{f}-$ and (b) $\mathrm{b}-\mathrm{Co}_{3} \mathrm{O}_{4}$. The inset is the corresponding $\mathrm{BJH}$ pore size distribution profile.

\subsection{Electronic Property from Optical Test}

Optical band gaps have been found correlated with the electrical conductivity of the electrode materials, which affects the supercapacitive performances [45]. The optical properties of the dilute cobalt oxide solutions in ethanol were characterized by UV/Vis/NIR spectroscopy. The bandgap of the cobalt oxide, a p-typed semiconductor, was influenced by the particle size, shape, and dimensions. Fig. 4 shows the UV-Vis absorbance spectrum of the cobalt oxides. Three absorption bands $\left(276,481\right.$, and $778 \mathrm{~nm}$ for $\mathrm{f}-\mathrm{Co}_{3} \mathrm{O}_{4}, 279,490$, and $780 \mathrm{~nm}$ for b- $\mathrm{Co}_{3} \mathrm{O}_{4}$, respectively) are in agreement with the $\mathrm{Co}_{3} \mathrm{O}_{4}$ band structure [46]. The optical band gap was determined using Tauc plot using Eq. (1) [47]:

$$
\alpha h v=\left(h v-E_{g}\right)^{\mathrm{n}}
$$

where $\alpha, \mathrm{h}, v$, and $E_{g}$ is the absorbance coefficient, planck constant, photon frequency, and photonic energy band gap, respectively. The parameter $\mathrm{n}$ is a number associated with different types of electronic transitions: $n$ is $1 / 2$ for direct-allowed (the minimum energy level of the 
lowest conduction band positioned directly under the maximum of the highest valence band in $\mathrm{k}$ space) and is 2 for indirect-allowed (the minimum energy level of the lowest conduction band shifted relative to the maximum of the highest valence band, and the lowest-energy interband transition must then be accompanied by phonon excitation) [48]. The value of the optical bandgap can be obtained by extrapolating the linear portion of the curve. The best fitting gives $n=1 / 2$, indicating a direct allowed transition for the $\mathrm{Co}_{3} \mathrm{O}_{4}$ samples. Two optical transitions, 0.62 and $2.68 \mathrm{eV}$ for $\mathrm{f}-\mathrm{Co}_{3} \mathrm{O}_{4}, 0.73$ and $2.72 \mathrm{eV}$ for $\mathrm{b}-\mathrm{Co}_{3} \mathrm{O}_{4}$, respectively, are observed in the Tauc plot. The lower and higher band gap values are assigned to $\mathrm{O}^{2-} \rightarrow \mathrm{Co}^{3+}$ and $\mathrm{O}^{2-} \rightarrow \mathrm{Co}^{2+}$ charge transfer process, respectively [49]. Generally, the band gap energy increases as the crystallite size is decreased, and vice versa [50]. The slightly smaller band gap values of $\mathrm{f}^{-} \mathrm{Co}_{3} \mathrm{O}_{4}$ compared to those of $b-\mathrm{Co}_{3} \mathrm{O}_{4}$ are consistent with the bigger particle size for the former as confirmed by the TEM analysis. Meanwhile, the smaller band gaps also suggest a better electrical conductivity of f- $-\mathrm{Co}_{3} \mathrm{O}_{4}$ than $\mathrm{b}-\mathrm{Co}_{3} \mathrm{O}_{4}$.
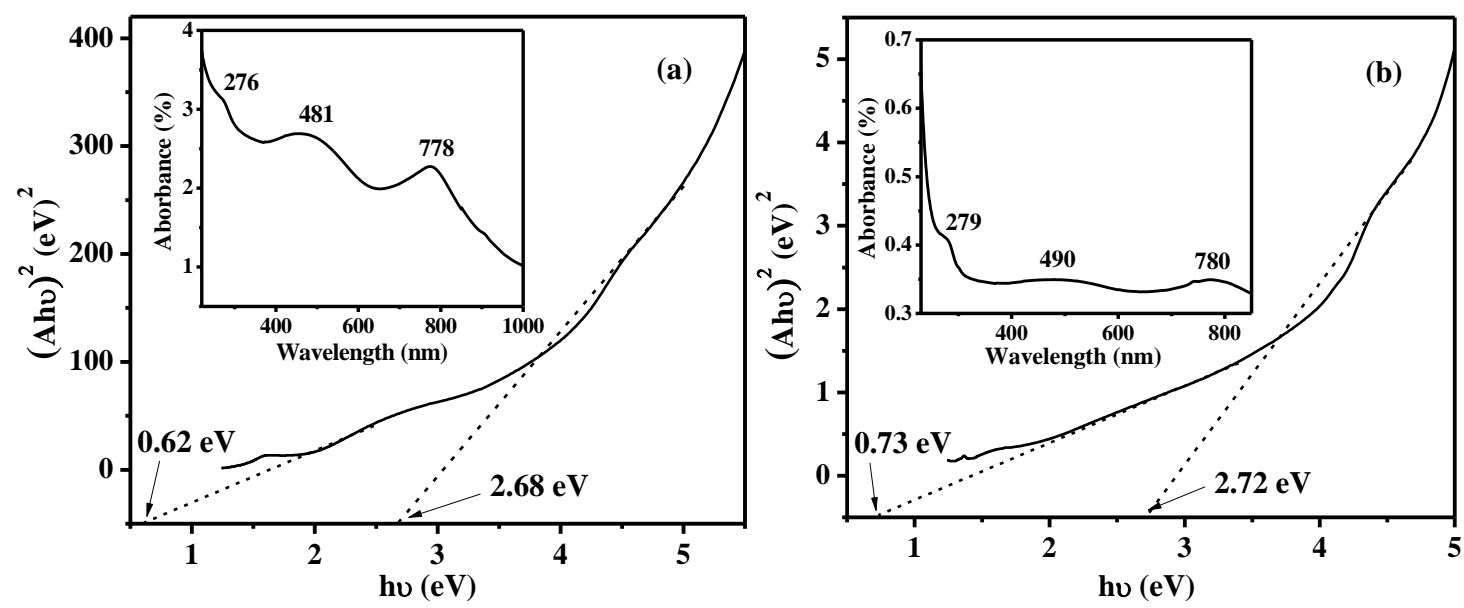

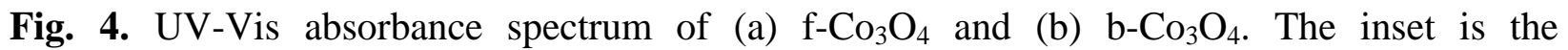
corresponding Tauc plot.

\subsection{Electrochemical Analysis}


To study capacitive properties and ion diffusion kinetics of $\mathrm{Co}_{3} \mathrm{O}_{4} / \mathrm{CP}$ electrodes, cyclic voltammetry $(\mathrm{CV})$ curves at different scan rates $(0.2,0.1,0.05,0.02$, and $0.01 \mathrm{~V} / \mathrm{s})$ within a potential range of -0.1 to $0.5 \mathrm{~V}$ vs. SCE in $2 \mathrm{M} \mathrm{KOH}$ aqueous solution were plotted in Fig. $5 \mathrm{a} \& \mathrm{~b}$. Pure $\mathrm{CP}$ exhibits negligible current densities as demonstrated in our previous study and therefore not shown here. For cobalt oxide based electrode materials, there are usually two redox transitions, around $\sim 0.2$ and $0.3 \mathrm{~V}$, respectively [51], corresponding to the oxidation/reduction of $\mathrm{Co}_{3} \mathrm{O}_{4}$ as follows [52]:

$$
\begin{aligned}
& \mathrm{Co}_{3} \mathrm{O}_{4}+\mathrm{OH}^{-}+\mathrm{H}_{2} \mathrm{O} \longleftrightarrow 3 \mathrm{CoOOH}+\mathrm{e}^{-} \\
& \mathrm{CoOOH}+\mathrm{OH}^{-} \longleftrightarrow \mathrm{CoO}_{2}+\mathrm{H}_{2} \mathrm{O}+\mathrm{e}^{-}
\end{aligned}
$$

In the present study, the two oxidation and reduction peaks overlap with each other, leaving only one oxidation peak $\mathrm{A}$ and one reduction peak $\mathrm{A}^{\prime}$, which are also reported in the mesoporous cobalt oxide nanowires electrode materials $[53,54]$. A positive shift in the anodic peak potential is observed with increasing the scan rate, taken $\mathrm{f}_{-} \mathrm{Co}_{3} \mathrm{O}_{4} / \mathrm{CP}$ for example, $0.386 \mathrm{~V}$ at $0.01 \mathrm{~V} / \mathrm{s}$ and $0.407 \mathrm{~V}$ at $0.2 \mathrm{~V} / \mathrm{s}$. This phenomenon is explained by the scan rate dependent diffusion of $\mathrm{OH}^{-}$ ions to the electrode material, where both the outer- and inner-pore surfaces are utilized at lower scan rates and only the outer pores will be accessed by the $\mathrm{OH}^{-}$ions at higher scan rates [55]. For both $\mathrm{f}-\mathrm{Co}_{3} \mathrm{O}_{4} / \mathrm{CP}$ and $\mathrm{b}-\mathrm{Co}_{3} \mathrm{O}_{4} / \mathrm{CP}$, an almost linear/quasi-linear relationship is established between the anodic peak current density and the applied scan rate, insets of Fig. 5a\&b, indicating the surface redox reactions occurring in the cobalt oxides/CP electrodes during the redox reactions [37]. 

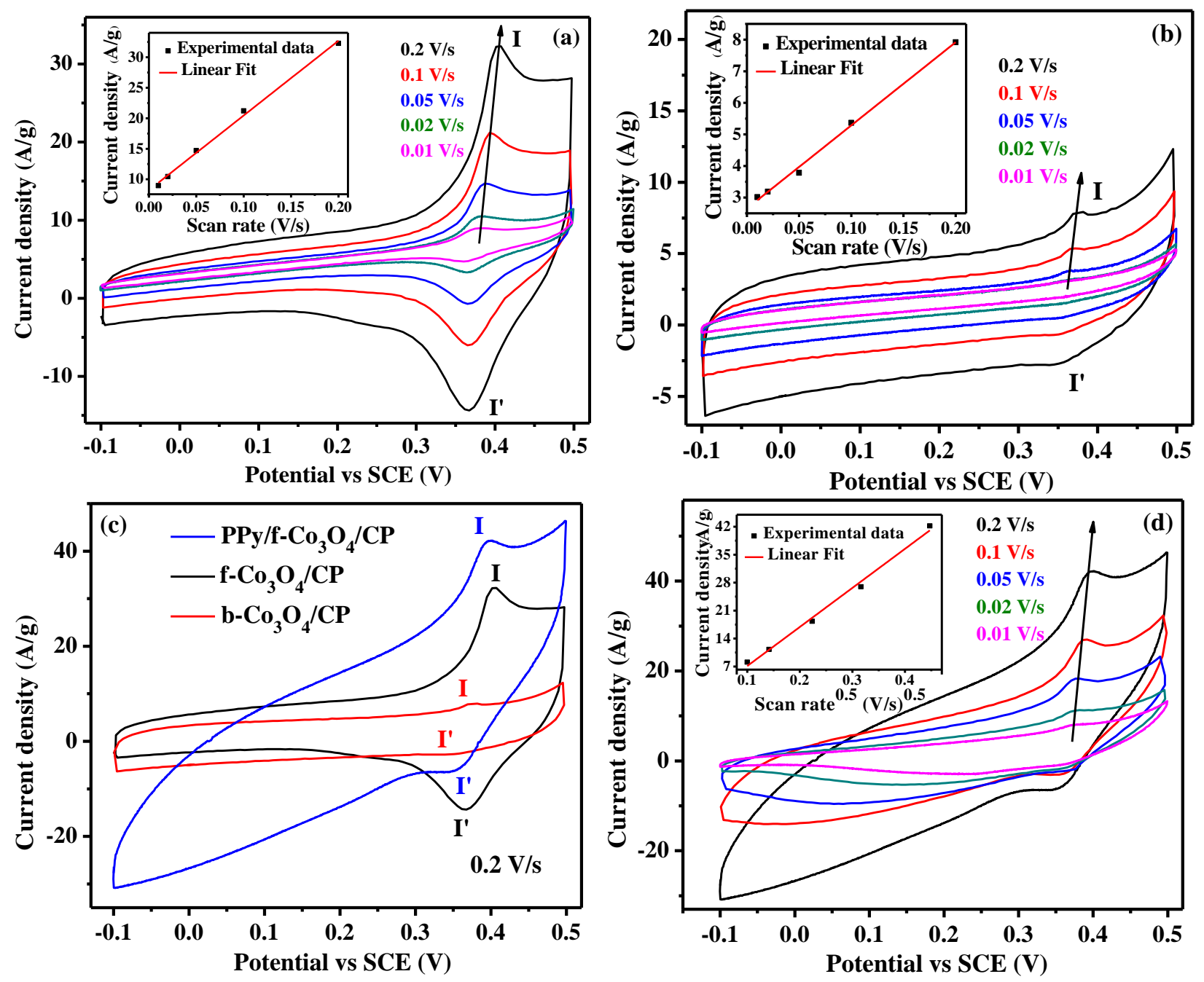

Fig. 5. (a) $\mathrm{CV}$ comparison at a scan rate of $0.2 \mathrm{~V} / \mathrm{s}$ in $2.0 \mathrm{M} \mathrm{KOH}$ aqueous solution and $\mathrm{CV}$ curves of (b) $\mathrm{f}-\mathrm{Co}_{3} \mathrm{O}_{4} / \mathrm{CP}$, (c) b- $\mathrm{Co}_{3} \mathrm{O}_{4} / \mathrm{CP}$, and (d) $\mathrm{PPy} / \mathrm{f}-\mathrm{Co}_{3} \mathrm{O}_{4} / \mathrm{CP}$ electrodes at different scan rates.

In comparison, the $\mathrm{f}-\mathrm{Co}_{3} \mathrm{O}_{4} / \mathrm{CP}$ demonstrates better defined redox peaks and higher current densities than the b- $\mathrm{Co}_{3} \mathrm{O}_{4} / \mathrm{CP}$, For example at $0.2 \mathrm{~V} / \mathrm{s}$, Fig. $5 \mathrm{c}$, indicating more energy stored in the latter [56]. This phenomenon is mainly due to higher specific surface area and pore volume of the unique porous morphology of $\mathrm{f}-\mathrm{Co}_{3} \mathrm{O}_{4}$, which facilitate the accessibility of the $\mathrm{OH}^{-}$ions to the electrode materials for faster redox reactions whereas the condensed $\mathrm{b}-\mathrm{Co}_{3} \mathrm{O}_{4}$ does not favor 
the $\mathrm{OH}^{-}$ions diffusion. The conclusion is confirmed by the much higher ion diffusion coefficient $D$ in the former $\left(5.2 \times 10^{-11}\right.$ vs. $\left.7.0 \times 10^{-12} \mathrm{~cm}^{2} / \mathrm{s}\right)$ according to Randles-Servcik in Eq. (2) [57]:

$$
i_{p}=2.72 \times 10^{5} n^{3 / 2} D^{1 / 2} C_{o} v^{1 / 2}
$$

where $D$ is the diffusion coefficient $\left(\mathrm{cm}^{2} / \mathrm{s}\right), C_{\mathrm{o}}$ is the concentration of the active ion in solution $\left(\mathrm{mol} / \mathrm{cm}^{3}\right), v$ is the sweep rate $(\mathrm{V} / \mathrm{s}), n$ is the number of electrons, here is 1 , and $i_{p}$ is the peak current density $\left(\mathrm{A} / \mathrm{cm}^{2}\right)$.

Considering the aforementioned better physicochemical properties of $\mathrm{f}-\mathrm{Co}_{3} \mathrm{O}_{4}$ than $\mathrm{b}-\mathrm{Co}_{3} \mathrm{O}_{4}$, $\mathrm{f}-\mathrm{Co}_{3} \mathrm{O}_{4}$ is incorporated with PPy to prepare composites for electrochemical capacitor applications. PPy was potentiodynamically electropolymerized on $\mathrm{f}-\mathrm{Co}_{3} \mathrm{O}_{4} / \mathrm{CP}$ to fabricate $\mathrm{PPy} / \mathrm{Co}_{3} \mathrm{O}_{4} / \mathrm{CP}$ ternary composites at a scan rate of $0.05 \mathrm{~V} / \mathrm{s}$ for 2 cycles in an aqueous solution containing $0.05 \mathrm{M}$ pyrrole monomers and $0.1 \mathrm{M} \mathrm{KNO}_{3}$. The growth of PPy on $\mathrm{f}-\mathrm{Co}_{3} \mathrm{O}_{4} / \mathrm{CP}$ is shown in Fig. 6.

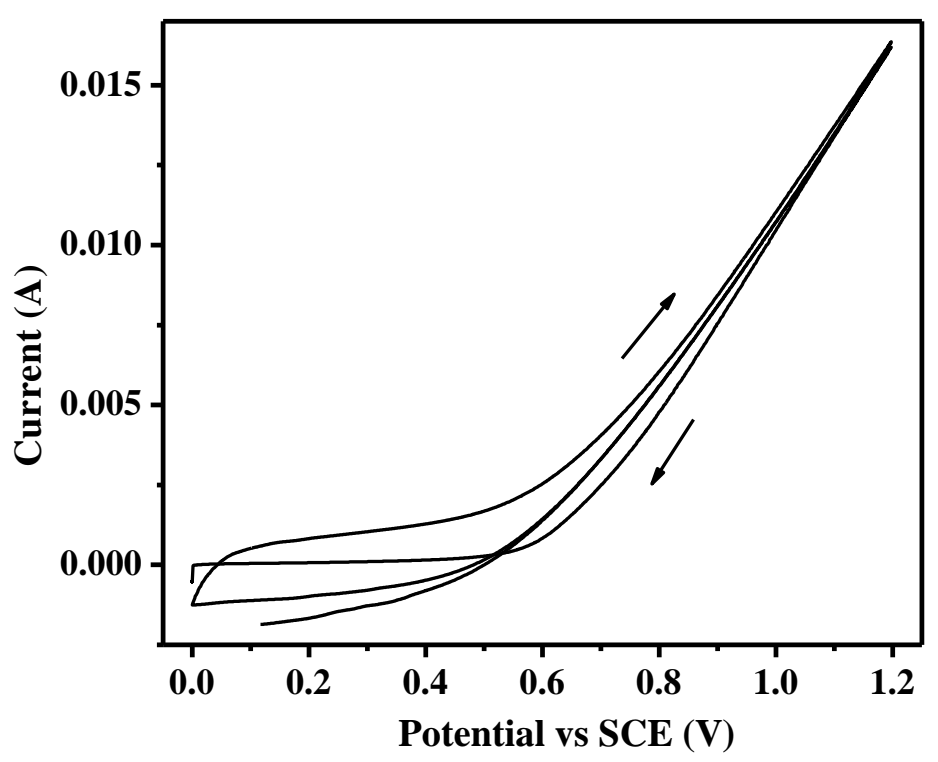

Fig. 6. Electropolymerization of polypyrrole onto on $\mathrm{f}-\mathrm{Co}_{3} \mathrm{O}_{4} / \mathrm{CP}$ for 2 cycles at a scan rate of $0.05 \mathrm{~V} / \mathrm{s}$ in the aqueous solution containing $0.05 \mathrm{M}$ pyrrole and $0.1 \mathrm{M} \mathrm{KNO}_{3}$. 
The mass and thickness of the PPy polymer on the composite films can be estimated from Eqs. (3\&4) [58]:

$$
\begin{gathered}
m=\frac{Q}{F} \cdot \frac{M_{m}+\gamma M_{d}}{2+\gamma} \\
d=\frac{m}{2 \rho A}
\end{gathered}
$$

where $Q$ is the total Faradic charges consumed in the electropolymerization, $F$ is Faraday constant $(96485 \mathrm{C} / \mathrm{mol}), \gamma$ is the doping density (0.33 for polypyrrole) [59], $M_{m}$ and $M_{d}$ are the

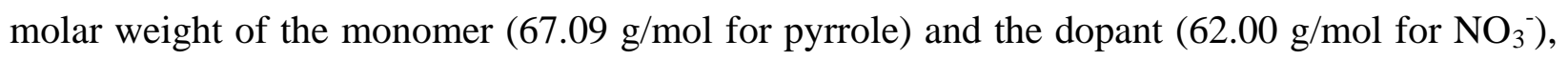
respectively, $d$ is the thickness of the PPy thin film on the carbon paper, $\rho$ is the density of the PPy $\left(1.5 \mathrm{~g} / \mathrm{cm}^{3}\right)$ [60], and $A$ is the surface area of the composite film. The mass is calculated to be $6.58 \times 10^{-8} \mathrm{~g}$ and the thickness is around $7.3 \mathrm{~nm}$. The PPy nanocoating can also be convinced by the SEM images, Fig. S1. The $\mathrm{f}-\mathrm{Co}_{3} \mathrm{O}_{4}$ particles are apparently observed uniformly distributed on the CP, Fig. S1a, and became less obvious after the PPy coating, Fig. S1b, suggesting the formation of PPy network on the $\mathrm{f}-\mathrm{Co}_{3} \mathrm{O}_{4} / \mathrm{CP}$.

Even the mass of PPy is negligible, the effect of PPy on enhancing the current densities is significant. Compared to $\mathrm{f}-\mathrm{Co}_{3} \mathrm{O}_{4} / \mathrm{CP}, \mathrm{PPy} / \mathrm{f}-\mathrm{Co}_{3} \mathrm{O}_{4} / \mathrm{CP}$ exhibits much higher current densities in addition to the redox peaks (A/A') ascribed to cobalt oxide, indicating the Faradic current contribution from the PPy thin film. To study the PPy nanocoating effect on the ion diffusion kinetics, $\mathrm{CV}$ curves of PPy/f- $\mathrm{Co}_{3} \mathrm{O}_{4} / \mathrm{CP}$ at different scan rates were also obtained, Fig. $5 \mathrm{~d}$. Interestingly, a linear relationship between the square root of scan rate and the peak current density is found for $\mathrm{PPy} / \mathrm{f}-\mathrm{Co}_{3} \mathrm{O}_{4} / \mathrm{CP}$, suggesting a diffusion-limited redox process, which is 
usually observed in the polymer thin film electrodes $[61,62]$. The varied ion diffusion behaviors imply the morphology difference brought by the PPy coating on the cobalt oxide.

Galvanostatic charge-discharge (GCD) measurements at a current density of $50 \mathrm{~A} / \mathrm{g}$ and other different current densities $(40,20$, and $10 \mathrm{~A} / \mathrm{g}$ ) were further carried out to investigate the supercapacitive properties of $\mathrm{f}-\mathrm{Co}_{3} \mathrm{O}_{4} / \mathrm{CP}$ and $\mathrm{PPy} / \mathrm{f}-\mathrm{Co}_{3} \mathrm{O}_{4} / \mathrm{CP}$ in $2.0 \mathrm{M} \mathrm{KOH}$ aqueous solution from -0.1 to $0.5 \mathrm{~V}$ vs. SCE using Eq. (5) [45]:

$$
C_{s}=(i \times t) /(m \times \Delta V)
$$

where $C_{s}$ is the specific capacitance in $\mathrm{F} / \mathrm{g}, i$ is the discharge current in $\mathrm{A}, t$ is the discharge time in $\mathrm{s}, m$ is the mass of the active materials (the mass of cobalt oxides in view of little PPy electropolymerized) in the electrode in $\mathrm{g}, \Delta V$ is the scanned potential window (excluding IR drop arising from the internal resistance of the cell at the beginning of the discharge process) in V. Fig. 7 shows the typical potential responses of the samples at a current density of $50 \mathrm{~A} / \mathrm{g}$, Fig. 7a, and the specific capacitances of the electrode materials at different current densities, Fig. $7 \mathrm{~b}$. In consistence with the $\mathrm{CV}$ results, the non-linear and asymmetric GCD curves suggest a pseudocapacitance behavior of the electrode materials. The results show that the b- $\mathrm{Co}_{3} \mathrm{O}_{4} / \mathrm{CP}$ displays the highest IR drop whereas the $\mathrm{f}-\mathrm{Co}_{3} \mathrm{O}_{4} / \mathrm{CP}$ and $\mathrm{PPy} / \mathrm{f}-\mathrm{Co}_{3} \mathrm{O}_{4} / \mathrm{CP}$ show similar IR drop, Fig. 7a, indicating the highest resistance in the former. The PPy/f- $-\mathrm{Co}_{3} \mathrm{O}_{4} / \mathrm{CP}$ displays the longest discharge time, followed by the $\mathrm{f}-\mathrm{Co}_{3} \mathrm{O}_{4} / \mathrm{CP}$, and then $\mathrm{b}-\mathrm{Co}_{3} \mathrm{O}_{4} / \mathrm{CP}$. The specific capacitance of the electrode materials against the current density is plotted in Fig. 7b. The specific capacitance values of $\mathrm{f}-\mathrm{Co}_{3} \mathrm{O}_{4} / \mathrm{CP}$ and $\mathrm{b}-\mathrm{Co}_{3} \mathrm{O}_{4} / \mathrm{CP}$ is 40.9 and $22.0 \mathrm{~F} / \mathrm{g}$, respectively, at a high current density of $10 \mathrm{~A} / \mathrm{g}$, comparable to those reported for cobalt oxide nanotubes $(70 \mathrm{~F} / \mathrm{g})$ and hexagonal plates $(15 \mathrm{~F} / \mathrm{g})$ at a much lower current density of $1.0 \mathrm{~A} / \mathrm{g}$ [63]. As aforementioned, 
the porous nanosheet structure of the $\mathrm{f}-\mathrm{Co}_{3} \mathrm{O}_{4} / \mathrm{CP}$ is capable of providing faster ion and electron transfer and larger reaction surface area, giving rise to better electrochemical performances than the $\mathrm{b}-\mathrm{Co}_{3} \mathrm{O}_{4} / \mathrm{CP}$. It's noteworthy that the corresponding specific capacitance is significantly increased to $398.4 \mathrm{~F} / \mathrm{g}$ for the $\mathrm{PPy} / \mathrm{f}-\mathrm{Co}_{3} \mathrm{O}_{4} / \mathrm{CP}$. The value is much higher than the reported 150 $\mathrm{F} / \mathrm{g}$ for porous cobalt oxide at a much lower current density of $1.0 \mathrm{~A} / \mathrm{g}$ [64]. The pseudocapacitance contributions from PPy, as confirmed by the CV result, is mainly attributed to the improved capacitive performances.
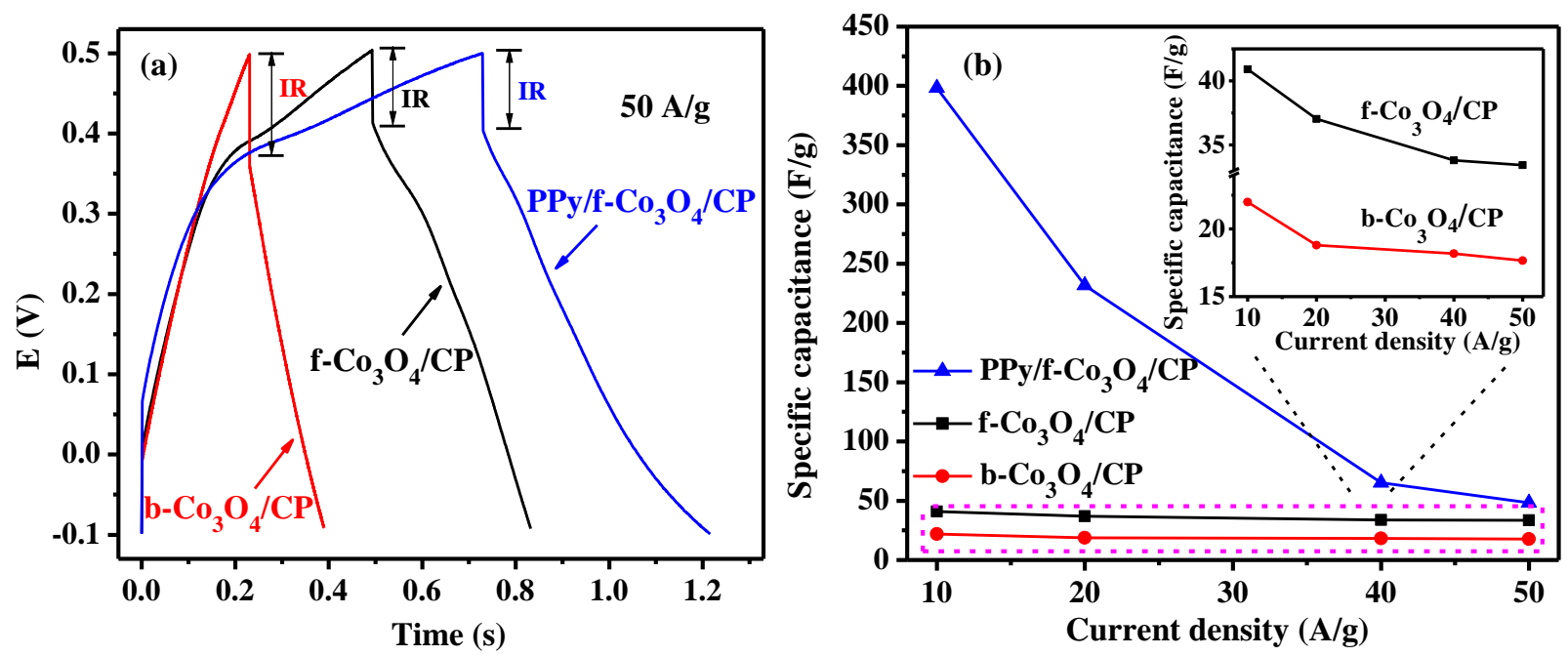

Fig. 7. (a) Charge-discharge curves $\mathrm{f}-\mathrm{Co}_{3} \mathrm{O}_{4} / \mathrm{CP}, \mathrm{b}-\mathrm{Co}_{3} \mathrm{O}_{4} / \mathrm{CP}$, and $\mathrm{PPy} / \mathrm{f}-\mathrm{Co}_{3} \mathrm{O}_{4} / \mathrm{CP}$ electrodes at $50 \mathrm{~A} / \mathrm{g}$, and (b) current density dependent specific capacitance in potential range from -0.1 to 0.5 $\mathrm{V}$ in $2.0 \mathrm{M} \mathrm{KOH}$ aqueous solution. The inset is the magnified view of the specific capacitance for $\mathrm{f}-\mathrm{Co}_{3} \mathrm{O}_{4} / \mathrm{CP}$ and $\mathrm{b}-\mathrm{Co}_{3} \mathrm{O}_{4} / \mathrm{CP}$.

The energy density, $E$, and the power density, $P$ of the electrode materials were calculated from Eqs. (6\&7) [65]:

$$
\begin{gathered}
E=\frac{C_{s} \Delta V^{2}}{7.2} \\
P=\frac{3600 E}{t}
\end{gathered}
$$


where $E$ is the energy density in $\mathrm{Wh} / \mathrm{kg}, P$ is the power density in $\mathrm{kW} / \mathrm{kg}$. $C_{s}$ is the specific capacitance in $\mathrm{F} / \mathrm{g}, \Delta V$ is the scanned potential window (excluding IR drop at the beginning of the discharge) in $\mathrm{V}, t$ is the discharge time in $\mathrm{s}$.

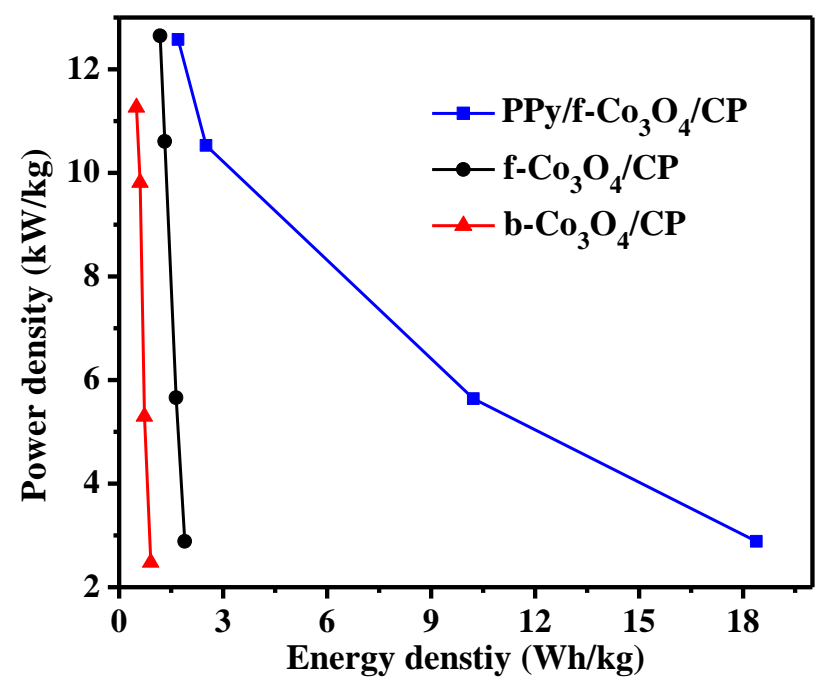

Fig. 8. Ragone plots of $\mathrm{f}-\mathrm{Co}_{3} \mathrm{O}_{4} / \mathrm{CP}, \mathrm{b}-\mathrm{Co}_{3} \mathrm{O}_{4} / \mathrm{CP}$, and $\mathrm{PPy} / \mathrm{f}-\mathrm{Co}_{3} \mathrm{O}_{4} / \mathrm{CP}$ composite electrodes.

Fig. 8 shows the corresponding Ragone plots of the f- $\mathrm{Co}_{3} \mathrm{O}_{4} / \mathrm{CP}, \mathrm{b}-\mathrm{Co}_{3} \mathrm{O}_{4} / \mathrm{CP}$, and PPy/f$\mathrm{Co}_{3} \mathrm{O}_{4} / \mathrm{CP}$ obtained from the GCD measurements. The f- $\mathrm{Co}_{3} \mathrm{O}_{4} / \mathrm{CP}$ and $\mathrm{PPy} / \mathrm{f}-\mathrm{Co}_{3} \mathrm{O}_{4} / \mathrm{CP}$ show both higher power and energy densities than the $\mathrm{b}-\mathrm{Co}_{3} \mathrm{O}_{4} / \mathrm{CP}$ benefitting from the less IR drop and higher specific capacitances [66]. Meanwhile, the $\mathrm{PPy} / \mathrm{f}-\mathrm{Co}_{3} \mathrm{O}_{4} / \mathrm{CP}$ has much improved energy densities compared to $\mathrm{f}-\mathrm{Co}_{3} \mathrm{O}_{4} / \mathrm{CP}$. For example, at a high current density of $50 \mathrm{~A} / \mathrm{g}$, the corresponding energy densities are $1.7,1.2$, and $0.5 \mathrm{Wh} / \mathrm{kg}$ at a power densities $12.6,12.6,11.3$ $\mathrm{kW} / \mathrm{kg}$ for $\mathrm{PPy} / \mathrm{f}-\mathrm{Co}_{3} \mathrm{O}_{4} / \mathrm{CP}, \mathrm{f}-\mathrm{Co}_{3} \mathrm{O}_{4} / \mathrm{CP}$ and $\mathrm{b}-\mathrm{Co}_{3} \mathrm{O}_{4} / \mathrm{CP}$, respectively. The energy density is increased to $18.4,1.9$, and $0.9 \mathrm{Wh} / \mathrm{kg}$ at a lower power densities of $2.9,2.9$, and $2.5 \mathrm{~kW} / \mathrm{kg}$.

To obtain a further fundamental understanding of the properties of the electrode materials, EIS was employed. Fig. 9 shows the corresponding Nyquist plots. The equivalent series 
resistances $\left(R_{s}\right.$, arising from the ohmic resistance of the electrolyte, the internal resistance of the electrode materials, and contact resistance between electrodes and current collectors) can be obtained from the first intercept in the real axis [13]. A semicircle, the diameter of which represents the charge transfer resistance at the electrode/electrolyte interface, was observed in both electrodes in the high frequency region. The PPy/f- $\mathrm{Co}_{3} \mathrm{O}_{4} / \mathrm{CP}$ exhibits much smaller $R_{c t}$ than $\mathrm{f}-\mathrm{Co}_{3} \mathrm{O}_{4} / \mathrm{CP}$ cobalt oxide, indicating a facilitated charge transfer upon the introduction of the PPy film. The Warburg resistance observed in the lower frequency of the electrodes is related to the frequency dependent ion diffusion/transport in the electrolyte [14]. An equivalent circuit consisting of $R_{s}, R_{c t}$, and CPE is proposed using ZsimpWin electrochemical software. CPE, as defined in Eq. (8) [67], is a constant phase element that is employed considering the deviation of from ideal capacitor behaviors due to inhomogeneity and roughness of the electrodes

$$
Z_{C P E}=T_{C P E}(j w)^{-n}
$$

where $Z_{C P E}$ is the complex impedance of CPE, $T_{C P E}$ and $n$ are frequency-independent constants, and $w$ is the angular frequency ( $w=2 \pi f, f$ is the frequency). $n$ is related to the roughness of the electrode surface and ranges from 0 to 1 for an CPE. $n$ is 0 for a resistor, 1 for an ideal capacitor, and 0.5 for a Warburg impedance (mass transfer impedance). Table 1 gives the fitting values of the elements. The $R_{s}$ of PPy/f- $\mathrm{Co}_{3} \mathrm{O}_{4} / \mathrm{CP}$ is around 2.62 $\Omega$, lower than that (3.06 $\Omega$ ) of $\mathrm{f}-\mathrm{Co}_{3} \mathrm{O}_{4}$. The difference in $n$ indicates a morphology change by the induction of PPy nanocoating on the f$\mathrm{Co}_{3} \mathrm{O}_{4}$. Meanwhile, the $R_{c t}$ of $\mathrm{PPy} / \mathrm{f}-\mathrm{Co}_{3} \mathrm{O}_{4} / \mathrm{CP}$ is $152.4 \Omega$, which is much lower than that (513.9 $\Omega$ ) of $\mathrm{f}-\mathrm{Co}_{3} \mathrm{O}_{4} / \mathrm{CP}$. The remarkably reduced $R_{c t}$ is inferred to contribute to improved electrochemical properties. The higher value of $\mathrm{CPE}, 0.002377$ in $\mathrm{PPy} / \mathrm{f}-\mathrm{Co}_{3} \mathrm{O}_{4} / \mathrm{CP}$ compared with 0.001682 in $\mathrm{f}-\mathrm{Co}_{3} \mathrm{O}_{4} / \mathrm{CP}$, is in good agreement with the $\mathrm{CV}$ and GCD results. Meanwhile, 
the slighly larger mass transfer resistance $Z_{w}$ witnessed in $\mathrm{PPy} / \mathrm{f}-\mathrm{Co}_{3} \mathrm{O}_{4} / \mathrm{CP}$ than $\mathrm{f}-\mathrm{Co}_{3} \mathrm{O}_{4} / \mathrm{CP}$ ( 0.03 vs. $0.06 \Omega$ ), further confirms the diffusion-limited behaviors in the $\mathrm{CV}$ measurements.

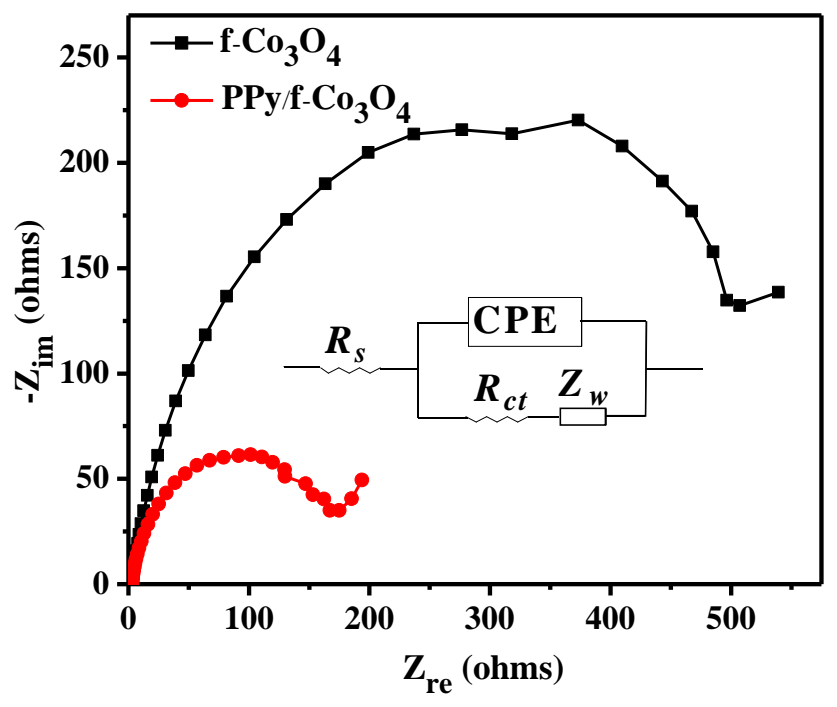

Fig. 9. Complex-plane plots of $\mathrm{f}-\mathrm{Co}_{3} \mathrm{O}_{4} / \mathrm{CP}$ and $\mathrm{PPy} / \mathrm{f}-\mathrm{Co}_{3} \mathrm{O}_{4} / \mathrm{CP}$. The inset is an expanded view of the Nyquist plot at the high frequency region and the equivalent circuit of the electrodes.

\section{Table 1}

Fitting parameters of $\mathrm{f}-\mathrm{Co}_{3} \mathrm{O}_{4} / \mathrm{CP}$ and $\mathrm{PPy} / \mathrm{f}-\mathrm{Co}_{3} \mathrm{O}_{4} / \mathrm{CP}$ in the equivalent circuit model.

\begin{tabular}{ccc}
\hline & $\mathbf{f}-\mathrm{Co}_{3} \mathbf{O}_{4} / \mathrm{CP}$ & $\mathbf{P P y} / \mathbf{f}-\mathrm{Co}_{3} \mathbf{O}_{4} / \mathrm{CP}$ \\
\hline$R_{s}(\Omega)$ & 3.06 & 2.62 \\
$C P E(\mathrm{~F})$ & 0.001682 & 0.002377 \\
$n$ & 0.8699 & 0.8472 \\
$R_{c t}(\Omega)$ & 513.9 & 152.4 \\
$Z_{w}(\Omega)$ & 0.03 & 0.06 \\
\hline
\end{tabular}

The long-term charge-discharge cycling stability of $\mathrm{f}-\mathrm{Co}_{3} \mathrm{O}_{4} / \mathrm{CP}$ and $\mathrm{PPy} / \mathrm{f}-\mathrm{Co}_{3} \mathrm{O}_{4} / \mathrm{CP}$ is investigated at a current density of $50 \mathrm{~A} / \mathrm{g}$ after 1000 cycles, Fig. 10. The increased capacitance retention over $100 \%$ is caused by the activation of the electrodes [68], which is usually observed in the cobalt oxide based electrode materials. In the case of $\mathrm{PPy} / \mathrm{f}-\mathrm{Co}_{3} \mathrm{O}_{4} / \mathrm{CP}$, the capacitance retention is around $100.0 \%$, indicating a good cycling stability of the ternary composite electrode. 


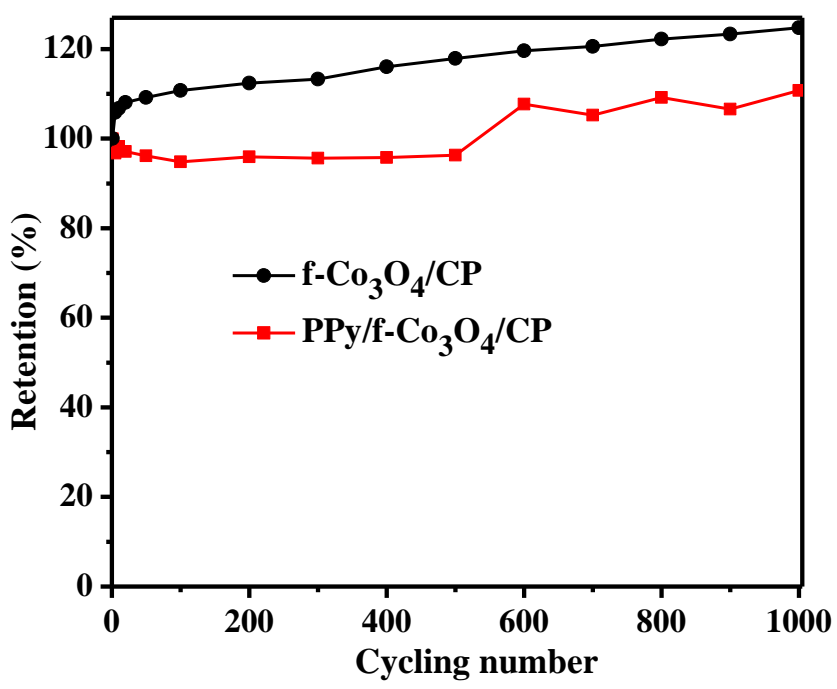

Fig. 10. Capacitance retention of $\mathrm{f}-\mathrm{Co}_{3} \mathrm{O}_{4} / \mathrm{CP}$ and $\mathrm{PPy} / \mathrm{f}-\mathrm{Co}_{3} \mathrm{O}_{4} / \mathrm{CP}$ at $50 \mathrm{~A} / \mathrm{g}$ in $2.0 \mathrm{M} \mathrm{KOH}$ aqueous solution after 1000 cycles.

\section{Conclusions}

Flower-like $\mathrm{Co}_{3} \mathrm{O}_{4}$ nanostructures have been successfully synthesized by a facile solvothermal method and used for fabricating $\mathrm{PPy} / \mathrm{f}-\mathrm{Co}_{3} \mathrm{O}_{4} / \mathrm{CP}$ ternary composites for electrochemical supercapacitor applications. The ball-like $\mathrm{Co}_{3} \mathrm{O}_{4}\left(\mathrm{~b}_{-} \mathrm{Co}_{3} \mathrm{O}_{4}\right)$ was also prepared for comparison. The $\mathrm{PPy} / \mathrm{f}-\mathrm{Co}_{3} \mathrm{O}_{4} / \mathrm{CP}$ ternary composites exhibit superior supercapacitive performances as compared with $\mathrm{f}-\mathrm{Co}_{3} \mathrm{O}_{4} / \mathrm{CP}$ and $\mathrm{b}-\mathrm{Co}_{3} \mathrm{O}_{4} / \mathrm{CP}$. The pseudocapacitance from PPy and remarkably reduced charge transfer resistance are inferred to be responsible for the enhanced electrochemical properties. The study shows a promising potential to fabricate stable, costeffective, and high performance PPy/metal oxide/carbon composites for supercapacitor applications.

\section{Acknowledgments}

The project is financially supported by the National Science Foundation (NSF) USANanoscale Interdisciplinary Research Team, and Materials Processing and Manufacturing (CMMI 10-30755) and nanomanufacturing (CMMI 13-14486). 


\section{References}

[1] Skotheim TA, Reynolds JR, editors. Handbook of conducting polymers. 3rd ed. Boca Raton: CRC Press; 2007.

[2] Gu H, Guo J, Wei H, Zhang X, Zhu J, Shao L, et al. Polymer 2014;55:944-50.

[3] Ding K, Jia H, Wei S, Guo Z. Ind Eng Chem Res 2011;50:7077-82.

[4] Xue K, Zhou S, Shi H, Feng X, Xin H, Song W. Sens Actuators B Chem 2014;203:412-6.

[5] Guo J, Gu H, Wei H, Zhang Q, Haldolaarachchige N, Li Y, et al. J Phys Chem C 2013;117:10191-202.

[6] Deshpande PP, Jadhav NG, Gelling VJ, Sazou D. J Coat Technol Res 2014;11:473-94.

[7] Sevilla M, Valle-Vigón P, Fuertes AB. Adv Funct Mater 2011;21:2781-7.

[8] Shao L, Cheng X, Wang Z, Ma J, Guo Z. J Membr Sci 2014;452:82-9.

[9] Gao J, Heeger AJ, Lee JY, Kim CY. Synth Met 1996;82:221-3.

[10] Takagi S, Makuta S, Veamatahau A, Otsuka Y, Tachibana Y. J Mater Chem 2012;22:22181-9.

[11] Seh ZW, Wang H, Hsu P-C, Zhang Q, Li W, Zheng G, et al. Energy Environ Sci 2014;7:672.

[12] Shi Y, Pan L, Liu B, Wang Y, Cui Y, Bao Z, et al. J Mater Chem A 2014;2:6086-91.

[13] Gu H, Wei H, Guo J, Haldolaarachige N, Young DP, Wei S, et al. Polymer 2013;54:597485.

[14] Wei H, Zhu J, Wu S, Wei S, Guo Z. Polymer 2013;54:1820-31.

[15] Wei H, Gu H, Guo J, Wei S, Guo Z. J Electrochem Soc 2013;160:G3038-45.

[16] Wei H, Yan X, Wu S, Luo Z, Wei S, Guo Z. J Phys Chem C 2012;116:25052-64.

[17] Patil BH, Jagadale AD, Lokhande CD. Synth Met 2012;162:1400-5.

[18] Wei H, Yan X, Li Y, Gu H, Wu S, Ding K, et al. J Phys Chem C 2012;116:16286-93.

[19] Wei H, Yan X, Li Y, Wu S, Wang A, Wei S, et al. J Phys Chem C 2012;116:4500-10.

[20] Sabouraud G, Sadki S, Brodie N. Chem Soc Rev 2000;29:283-93.

[21] Tao J, Liu N, Li L, Su J, Gao Y. Nanoscale 2014;6:2922-8.

[22] Zhao Y, Liu J, Hu Y, Cheng H, Hu C, Jiang C, et al. Adv Mater 2013;25:591-5.

[23] Lu X, Dou H, Yuan C, Yang S, Hao L, Zhang F, et al. J Power Sources 2012;197:319-24.

[24] Wang J-G, Yang Y, Huang Z-H, Kang F. J Mater Chem 2012;22:16943-9.

[25] Zhang LL, Zhao XS. Chem Soc Rev 2009;38:2520-31.

[26] Zang J, Bao S-J, Li CM, Bian H, Cui X, Bao Q, et al. J Phys Chem C 2008;112:14843-7.

[27] Sharma RK, Rastogi AC, Desu SB. Electrochimica Acta 2008;53:7690-5.

[28] Zhou C, Zhang Y, Li Y, Liu J. Nano Lett 2013;13:2078-85.

[29] Qu Q, Zhu Y, Gao X, Wu Y. Adv Energy Mater 2012;2:950-5.

[30] Liu Y, Zhang B, Yang Y, Chang Z, Wen Z, Wu Y. J Mater Chem A 2013;1:13582-7.

[31] Mi H, Zhang X, Ye X, Yang S. J Power Sources 2008;176:403-9.

[32] Rakhi RB, Chen W, Cha D, Alshareef HN. Nano Lett 2012;12:2559-67.

[33] Lang J, Yan X, Xue Q. J Power Sources 2011;196:7841-6.

[34] Vijayakumar S, Ponnalagi AK, Nagamuthu S, Muralidharan G. Electrochimica Acta 2013;106:500-5.

[35] Wang G, Shen X, Horvat J, Wang B, Liu H, Wexler D, et al. J Phys Chem C 2009;113:4357-61.

[36] Xia X, Tu J, Mai Y, Wang X, Gu C, Zhao X. J Mater Chem 2011;21:9319-25. 
[37] Meher SK, Rao GR. J Phys Chem C 2011;115:15646-54.

[38] Dong S, Peng L, Liu D, Yang Q, Huang T. Bioelectrochemistry 2014;98:87-93.

[39] Liu P, Huang Y. RSC Adv 2013;3:19033-9.

[40] Ma J, Manthiram A. RSC Adv 2012;2:3187-9.

[41] Meher SK, Rao GR. J Phys Chem C 2011;115:15646-54.

[42] Shan Y, Gao L. Mater Chem Phys 2007;103:206-10.

[43] Lv Y, Gan L, Liu M, Xiong W, Xu Z, Zhu D, et al. J Power Sources 2012;209:152-7.

[44] Rouquerol F. Adsorption by powders and porous solids: principles, methodology and applications. 2014.

[45] Wei H, Gu H, Guo J, Wei S, Guo Z. ECS J Solid State Sci Technol 2013;2:M3008-14.

[46] Wang G, Shen X, Horvat J, Wang B, Liu H, Wexler D, et al. J Phys Chem C 2009;113:4357-61.

[47] Xi L, Tran PD, Chiam SY, Bassi PS, Mak WF, Mulmudi HK, et al. J Phys Chem C 2012;116:13884-9.

[48] Wei H, Ding D, Yan X, Guo J, Shao L, Chen H, et al. Electrochimica Acta 2014;132:58-66.

[49] Li H, Wang J, Chu Q, Wang Z, Zhang F, Wang S. J Power Sources 2009;190:578-86.

[50] Wang X, Chen X, Gao L, Zheng H, Zhang Z, Qian Y. J Phys Chem B 2004;108:16401-4.

[51] Park S, Kim S. Electrochimica Acta 2013;89:516-22.

[52] Wang D, Wang Q, Wang T. Inorg Chem 2011;50:6482-92.

[53] Xiao Y, Zhang A, Liu S, Zhao J, Fang S, Jia D, et al. J Power Sources 2012;219:140-6.

[54] Rakhi RB, Chen W, Cha D, Alshareef HN. Nano Lett 2012;12:2559-67.

[55] Meher SK, Justin P, Ranga Rao G. Nanoscale 2011;3:683-92.

[56] Shen J, Liu A, Tu Y, Foo G, Yeo C, Chan-Park MB, et al. Energy Environ Sci 2011;4:4220-9.

[57] Wei H, Yan X, Wang Q, Wu S, Mao Y, Luo Z, et al. Energy Environ Focus 2013;2:112-20.

[58] Arcila-Velez MR, Roberts ME. Chem Mater 2014;26:1601-7.

[59] Waltman RJ, Bargon J. Can J Chem 1986;64:76-95.

[60] Qi Z, Pickup PG. Chem Mater 1997;9:2934-9.

[61] Roberts ME, Wheeler DR, McKenzie BB, Bunker BC. J Mater Chem 2009;19:6977-9.

[62] Yue G, Wu J, Xiao Y, Lin J, Huang M, Lan Z. J Phys Chem C 2012;116:18057-63.

[63] Frackowiak E, Béguin F. Carbon 2001;39:937-50.

[64] Meng F, Fang Z, Li Z, Xu W, Wang M, Liu Y, et al. J Mater Chem A 2013;1:7235-41.

[65] Liu J, Jiang J, Bosman M, Fan HJ. J Mater Chem 2012;22:2419-26.

[66] Conway BE. Electrochemical supercapacitors: scientific fundamentals and technological applications. New York: Plenum Press; 1999.

[67] Orazem ME. Electrochemical impedance spectroscopy. Hoboken, N.J: Wiley; 2008.

[68] Du W, Liu R, Jiang Y, Lu Q, Fan Y, Gao F. J Power Sources 2013;227:101-5. 


\section{Graphical Abstract}

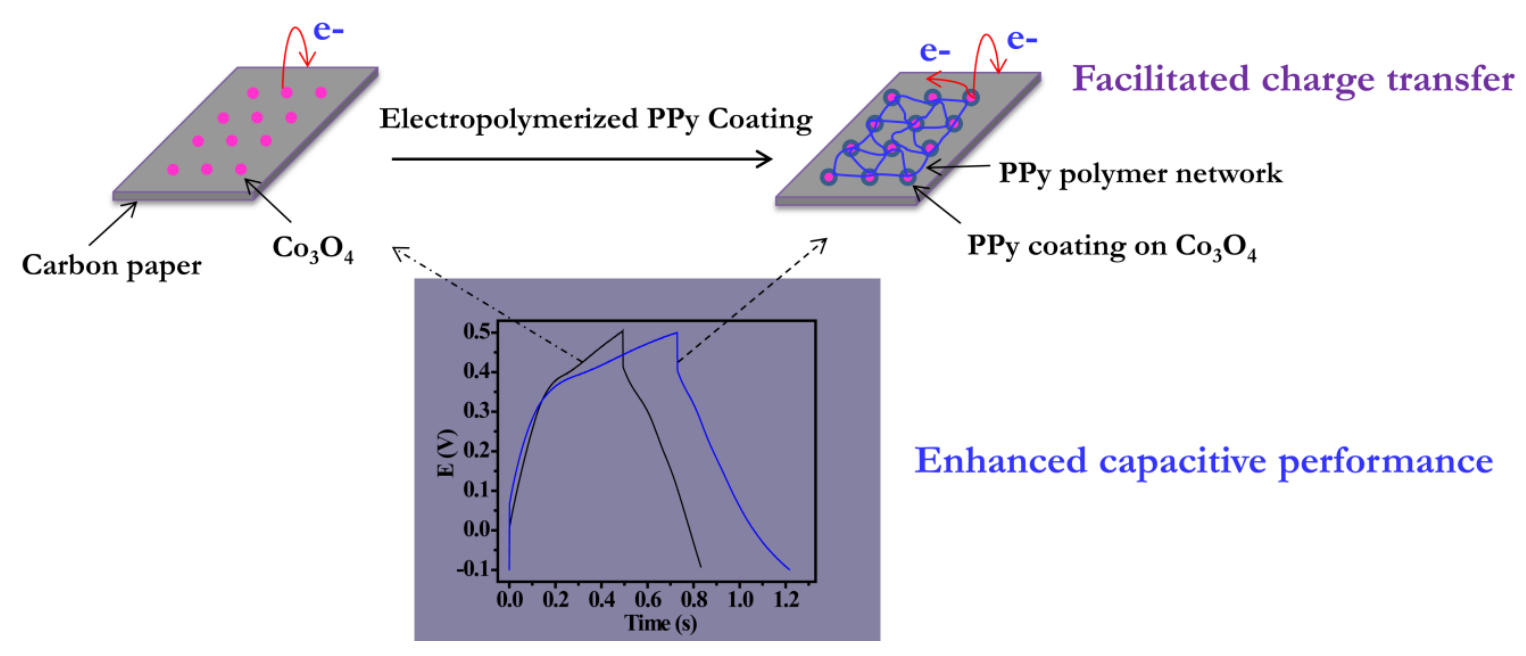

